Article

\title{
Locating Forced Migrants' Resources: Residency Status and the Process of Family Reunification in Finland
}

\author{
Johanna Hiitola \\ Migration Institute of Finland, 20100 Turku, Finland; E-Mail: johanna.hiitola@utu.fi
}

Submitted: 30 June 2019 | Accepted: 14 November 2019 | Published: 19 December 2019

\begin{abstract}
This article investigates how forced migrants residing in Finland utilise different types of resources in their efforts to reunite with their families. The data includes 36 group and individual interviews (2018-2019) with 43 Iraqi, Afghan, Somali, and Ethiopian forced migrants holding residence permits in Finland, who were either seeking to reunite with their families, or had already brought their families to Finland, or had attempted but failed to achieve family reunification. The results show that a variety of resources are needed to navigate the bureaucracies involved in family reunification. Economic resources in one's country of origin may be used to pay the high administrative and travel costs, as well as other fees required by government officials to obtain visas for family members. Cultural resources, such as education, are useful when one is trying to make sense of the complicated application process, or seeking work or educational opportunities in the new country. Different forms of social resources can be utilised to seek advice. However, the resources at the disposal of migrants are not the determining factor in attempts to successfully reunite with one's family. Although they are important, the success of the reunification process depends more on one's residency status and whether it allows family reunification without a high-income requirement.
\end{abstract}

\section{Keywords}

family migration; family reunification; forced migration; income requirements; social capital

\section{Issue}

This article is part of the issue "Social Inclusion beyond Borders: Utilization of Migrant Capital in Transnational and Diaspora Communities" edited by Sanna Saksela-Bergholm (University of Helsinki, Finland), Mari Toivanen (University of Helsinki, Finland) and Östen Wahlbeck (University of Helsinki, Finland).

(C) 2019 by the author; licensee Cogitatio (Lisbon, Portugal). This article is licensed under a Creative Commons Attribution 4.0 International License (CC BY).

\section{Introduction}

Temporal and spatial disconnections from home and intimate relations, together with the absence of family members, are inseparable from the phenomenon of forced migration. However, knowledge about family separation of forced migrants is mostly situated within psychology and trauma studies. These scholars suggest that family separation can have long-lasting effects, which include a variety of post-traumatic stress disorder symptoms (Nickerson, Bryant, Steel, Silove, \& Brooks, 2010; Rousseau, Mekki-Berrada, \& Moreau, 2001), depression, anxiety, and insomnia (Rousseau, Rufagari, Bagilishya, \& Measham, 2004; Wilmsen, 2013). It has also been reported that family separation hinders migrants from settling into their new country (Choummanivong, Poole, \&
Cooper, 2014). In addition, another strand of research has dealt with actors who implement family reunification policies (Eggebø, 2013; Pellander, 2015), and legislation by national and international courts (de Hart, 2007; Mustasaari, 2016). There is a gap in research in the area of migrants' own strategies for coping with family separation, and the administrative structures that help or hinder these processes. This article examines how forced migrants utilise various types of resources in their efforts to reunite with their families. I argue that the acquisition and utilization of capitals may be different when migration happens due to conflict or other lifethreatening circumstances.

As a consequence of the financial crisis in Europe, discourse on migrants as 'welfare expenditure' has shifted the discussion away from human rights con- 
cerns (Kofman, 2018). Several new restrictions within immigration legislation have been made across Europe, and Finland is no exception. The most significant change affecting refugees' and forced migrants' family lives in Finland happened in 2016, when the highincome limit was applied to migrants receiving international protection.

In principle, once a forced migrant receives a residence permit in Finland, he or she is eligible for family reunification. However, following an increase in the number of asylum seekers arriving in Finland in 2015-2016, the country adopted a number of restrictive migration policies, including several new restrictions on family reunification. For instance, with effect from 1 July 2016, Finland extended the income requirement for family reunification, also applying it to migrants who received a category of residency called subsidiary protection, regardless of their age. One category of protectionhumanitarian grounds-was omitted completely from the legislation.

At present, forced migrants are granted one of four different categories of residency in Finland: refugee (asylum); subsidiary protection; compassionate grounds; or residency based on being a victim of human trafficking. Additionally, some may apply for other statuses, for example based on work or study. However, none of the migrants in this research had such statuses (except for residency based on family relationships, which the transnational families of the 'sponsoring' migrants would receive), and no participants had residency based on being a victim of human trafficking. According to current Finnish legislation, migrants receiving their residency based on subsidiary protection or compassionate grounds have to fulfil specified income requirements. Furthermore, those with refugee status (asylum) on the grounds of persecution need to demonstrate they have a high level of income, if their application is not submitted within three-months of receiving residency. The monthly income requirement for someone with refugee status to bring a spouse and two children to Finland is 2600 euros after taxes, which corresponds to a monthly salary of almost 4000 euros. This figure is more than the average Finnish income, and is the highest ${ }^{1}$ income requirement in comparison to other Nordic countries (Sweden, Norway, Denmark).

Unlike many European countries, and all the other Nordic countries, Finland also requires migrants' transnational families, who are seeking residency through family reunification, to travel to an interview in a specific country instead of giving individuals a choice of interview locations and allowing them to decide. This is not an issue for those migrants who have a functioning Finnish Embassy in their country of citizenship but is a huge problem for those who do not; for example, Afghan migrants (many of whom live in Iran) have to travel to New Delhi, India, for this purpose. This detail in current Finnish pol- icy makes family reunification impossible for many, who simply cannot arrange travel to the interviews.

In view of the difficulties highlighted above, this article focuses on how forced migrants residing in Finland utilise different types of resources in their efforts to reunite with their families. The data in this study includes 36 group and individual interviews with 43 forced migrants from Afghanistan, Iraq, Somalia, and Ethiopia. All the interviewees are living in Finland. Their families are either already in Finland, or waiting abroad to be able to move to Finland. The distinction between 'forced' and 'voluntary' migration is often a blurred one. Many who, at first, seek asylum might later attempt to acquire a work- or study-related residence permit (see Erdal \& Oeppen, 2018). However, the participants are referred to as 'forced migrants' to stress the specific circumstances faced by those who seek asylum and are granted international protection (in Finland: asylum, subsidiary protection) or other humanitarian residence permits (in Finland: compassionate grounds, victim of human trafficking).

\section{Migrants' Resources and Family Migration}

This article investigates the role of migrants' capital in family migration and particularly in family reunification processes. I focus on the kinds of resources that migrants draw upon to enable them to live together with their families, or even simply be able to start the process of family reunification. 'Resources' in this article are understood to be much the same as capitals, which Bourdieu $(1986,1987)$ divides into economic, cultural, and social. In this section, I will draw on Bourdieu's theory of capitals and, particularly, show how the theory can be applied to understanding migrants' resources. Economic capital, according to Bourdieu (1986), refers to financial possibilities and differential (often generationally accumulated) wealth. Cultural capital most often comprises forms of education and knowledge regarding different cultural products and arts.

Social capital is perhaps the most studied form of capital in migration studies (Ryan, Erel, \& D’Angelo, 2015). It refers to the diverse social bonds that people accumulate and through which various benefits and values may be created. Migration scholars have especially analysed social networks (e.g., Koser \& Pinkerton, 2002; Lyytinen \& Kullenberg, 2015) and made significant contributions in understanding the different types of social capital migrants possess, such as bridging and bonding social capital (see Putnam, 2000). These studies offer insights into the accumulation, conversion, and utilisation of social capital by migrant communities. For example, Katila and Wahlbeck (2012) suggest that successful migrant business owners combine the resources available through Finnish and co-ethnic social ties, as well as local and transnational ties.

\footnotetext{
${ }^{1}$ Based on the website of the Swedish Migration Agency, The Danish Immigration Service, The Norwegian Directorate of Immigration, and the Finnish Immigration Service, as of October 2019.
} 
However, in migration studies, as Anthias and Cederberg (2009) suggest, social capital works slightly differently than in other sociological analyses. Migrants may have significant networks which offer certain benefits, such as esteem or practical assistance, but these networks do not always produce value in a way that would generate worth in a specific field, such as in a particular society (see also Anthias, 2007). Being able to transfer different capitals into 'symbolic capital' - a legitimized and recognized form of capital, a source of value in a specific field (see Skeggs, 1997)-is an essential aspect of different capitals in Bourdieu's (1987) theory. Anthias and Cederberg (2009) resolve this issue of non-transferrable migrant capital by naming migrant social capital a 'resource' rather than capital. I also use the term resource throughout this article to stress the temporary nature not only of social capital, but forced migrants' different beneficial networks, wealth, or education, for example.

Capitals are always produced and processed within a specific 'field' and their utilization might not be transferred to another field. However, Bourdieu distinguishes symbolic capital as a specific type of capital, which is formed from other capitals, but can be 'exchanged' between the fields (see Thomson, 2008). Economic capital, for example, may in many cases be used to purchase other types of capital, such as education. In this study, 'field' refers to the process of family reunification that the interviewed migrants aim to achieve.

In Bourdieu's work, it is essential to understand that although the capitals are very concrete, they are also 'embodied' (Bourdieu, 1986). Possessing different embodied capitals influences the way in which a person understands him/herself and the world around him/her. Cultural capital, for example, influences embodied dispositions, which have a bearing on where one feels at home-whether that be at a car dealership or a cocktail party. Feminist scholars have developed some of the core ideas of capital theory to intersectionally understand the experiences and choices of, for example, working class women (see Skeggs, 1997, 2004). Recently, a number of migration scholars have advanced this strand of social stratification theory (e.g., Anthias, 2012; Anthias \& Cederberg, 2009; Ryan et al., 2015), but the theoretical developments of intersectional social stratification theory have rarely focused on the specifics of forced migration as a significant issue (for example, Cederberg, 2015; Sanghera \& Thapar-Björkert, 2017).

Although feminist scholars working with capital theories have not fully discussed forced migration, many migration scholars have analysed migrant capital or resources at different stages of the (forced) migratory journey. For example, migrants' decision-making regarding migration destinations has been widely studied. Crawley and Hagen-Zanker $(2019$, p. 11) suggest that individual socio-economic characteristics shape the destinations that 'are, and are not, available to people.' So rather than relying on knowledge of migration policies in different countries, migrants' paths are mainly shaped by individ- ual resources, such as existing social networks in particular countries, previous education, and language skills (e.g., Richardson, 2010; Valenta \& Thorshaug, 2012).

Also, family migration has not been much studied within capital theory. Della Puppa's (2018) study is an exception. It suggests that migrant families are continuously struggling to be able to stay together. The study found that especially social and mobility capital are useful in dealing with precarious residency and the uncertainty of being able to stay together as a family. Eleonore Kofman (2018) compared migrants' economic capital in connection with the fulfilment of income requirements in the Netherlands, Norway, and the UK. She found that those without sufficient economic capital to meet the income requirements may use cultural capital to facilitate the development of coping strategies to overcome or reduce the duration of family separation. This article builds on and extends the previous scholarship by investigating the utilisation of existing resources of forced migrants with different residency categories in Finland. Given that there is limited scholarship on forced migrants' strategies in trying to fulfil the requirements of family reunification, this article points to directions for future research in how forced migrants utilize their existing resources. In addition to the often-described income and housing requirements, this article aims to also reveal the structural barriers-especially relevant to forced $\mathrm{mi}$ grants who come from countries where there is on-going conflict-which, in practice, often make it impossible to even submit the application for family reunification.

\section{Interviews with Forced Migrants}

The interviews in this study were conducted during 2018-2019 and consist of 36 group and individual interviews, either with the participants alone or with the participants and their family members. These semistructured interviews involved 43 forced migrants altogether (27 who arrived as adults and 16 who came as minors). Of the interviewees, 28 were men and 15 were women. One family was interviewed twice. The interviewees had lived in Finland for between one and eight years. The ages of the interviewees ranged from 17 to 61 years. In the following analysis, I will call the young migrants who had initially arrived as minors 'unaccompanied minors,' even though most of the interviewees were over 18 at the time of the interview. The unaccompanied minors had arrived in Finland when they were between 12 and 16 years old. The interviewees were from Afghanistan (32), Iraq (8), Somalia (2), and Ethiopia (1). Since the research assistants on the project, who had helped to recruit interviewees, belonged to Afghan, Iranian, and Iraqi diasporas, the number of Afghan and Iraqi interviewees was the highest. The interviews were conducted in Finnish, English, Dari, or Arabic, depending on the participants' language skills.

The main guiding ethical principle in this study was to 'do no harm,' following the Oxford Refugee Studies 
Centre's (2007) guidelines. However, recent refugee scholars have highlighted the need for a more reciprocal relationship with research participants. Instead of 'stealing stories,' scholars themselves should seek to benefit the vulnerable group (Krause, 2017; Mackenzie, McDowell, \& Pittaway, 2007). These issues were addressed in this study on the micro level by guiding the participants towards non-governmental organisations and officials who could help them with their often-complicated family reunification processes. On the macro level, the project team has actively engaged in the societal discussion about family reunification policies by stressing the effects of tightened policies on refugees' lives. The project plan, interview questions, consent form and other relevant documents were reviewed by the Ethics Committee of the University of Turku before the data collection (in Spring 2018). For the interviews with minors who were still living in a group home for young people, a separate research permit was sought from the group home, in addition to the consent of the interviewees themselves. All the identifying information, such as cities of origin, places of work, or specific attributable circumstances have been omitted from the interview quotations. The interviewees' names are pseudonyms.

The translated and transcribed data is kept on my password-protected computer. After the project ends, most of the data will be stored on the Finnish Social Science Data Archive to enable further use. The data has been arranged thematically to represent the different phases, or in some cases outcomes, of the family reunification processes, and the resources about which migrants spoke in connection with the different phases. The data was coded manually. Table 1 represents the resources, which each of the 35 families in the study had at their disposal (note that one family was interviewed twice, so the data includes 36 interviews).

As can be seen from Table 1, the families who were reunited had significantly more resources. The resource categories refer to 'minor economic' resources, when the family had some possessions (e.g., jewellery or a car), which they had been able to sell to fund their application fees and family's travel to interviews. 'Major economic' resources meant that the family was wealthy and was able to pay the fees without any difficulty or having to sell all their possessions. 'Cultural' resources refer to education, or a distinguished position as an artist. The families who had 'social' resources were able to draw on support from networks of people to keep their families safe. Finally, the category of 'acquired' refers to new social networks in Finland, who were able to either support the well-being of the 'sponsoring' migrant in Finland, or even in some cases help in the actual process of applying for family reunification.

\section{Migrant Resources and Family Reunification}

\subsection{Families Reunited}

Of the 35 families interviewed, only 11 had been successful in reuniting with their families; 12 had received negative initial decisions and were now awaiting the results of their appeals from the Administrative or Supreme Administrative Courts; and 12 had been refused at all court levels, or had not even been able to submit an application. The participants who had been successful in their applications either had at least some economic capital, or had arrived in Finland prior to the introduction of more stringent administrative barriers in recent years, such as the income requirement for family reunification for people who are granted subsidiary protection (brought into effect in 2016) and the requirement that one has to reside legally in the country where the application is submitted (brought into effect in 2011). In connection to the latter requirement, the main hardship that interviewees mentioned was that they could not acquire travel documents to go to the specific embassy assigned to them according to their country of birth. For example, Afghans living (or even born) in Iran could not submit their applications to the Finnish Embassy in Tehran, Iran, although Iranians were able to apply to this embassy for their family reunification. Instead Afghans living in Iran had to arrange travel to India in order to be interviewed, which required them first to travel to Afghanistan to attain the travel documents for going to India. Needless to say, this was impossible for many as they could not safely travel to Afghanistan.

The participants who had been successful in their applications were all recognised as refugees, so they were exempt from the high-income requirement if they submitted their application within the three-month time limit. In practice, the time limit had often been longer if the participants had been able to explain why they could not meet it. It is essential to note that no one in this study would have been able to reunite with their family if the income requirement had applied to them. So, rather than resources, one's grounds for residency and ability

Table 1. Resources of forced migrants attempting family reunification.

\begin{tabular}{lccccc}
\hline Stage of application & Minor economic & Major economic & Cultural & Social & Acquired \\
\hline Reunited (11) & 5 & 3 & 4 & 7 & 4 \\
\hline Waiting (12) & 1 & 1 & 1 & 6 & 8 \\
\hline Risk of permanent separation (12) & - & 1 & - & 2 & 10 \\
\hline
\end{tabular}

Note: $\mathrm{N}$, families $=35$. 
to apply without demonstrating a high income seemed to be decisive regarding who was able to bring their family to Finland.

All but one of the research participants' families had had to travel to interviews in a country which was not their country of residence. The interviewees had all had major difficulties arranging their families' travel. The Iraqis in this study described that their families had not been granted visas to submit their applications in Ankara, Turkey, which was their designated embassy. The families had to go through hardships to be able to travel, first to identify themselves at the embassy and later to be interviewed. At least two trips had been necessary, and in some cases they had to make the journey three times. A few families had stayed in Turkey to await the results of the process, but the stays had been expensive and their visas had run out before their cases were resolved. All of these arrangements required huge sums of money, and among the Iraqi participants it was most often the father who resided alone in Finland and arranged to pay the costs. Many fathers took out large loans from their friends to accommodate this.

The data only included one family from Somalia. This family had also had great difficulties travelling to the embassy in Ethiopia, where they were initially denied entry because the embassy refused to accept their Somali passports as identification. The one Ethiopian family in this study was the only one that had been able to submit their application without serious hardship, since the embassy was within the same country. Similarly, one Afghan family had been able to travel to Tehran for the interviews with only minor difficulties, because they had submitted their application in Iran before a policy change that required Afghans to submit their applications in New Delhi, India. Most other Afghans in the study had been unable to even start their processes, since travelling to India was impossible for these often-undocumented families. For an Afghan family living as forced migrants in Iran, for example, submitting the application would have meant first going back to Afghanistan and arranging tazkiras (Afghan birth certificates) and passports. Then they would have to put large sums of money into a bank account so as to be able to acquire a visa to India. Finally, the family would have had to travel from Afghanistan to India several times for identification and interviews, or arrange to stay in New Delhi for the duration of the application process. Most of these steps were impossible for poor families, which often consisted of single mothers with children. Others with more resources had managed to arrange the process, but were often in huge debt after paying all the costs.

Reza, a 45-year-old man from Afghanistan, was one of the few who had succeeded in his application process. He had arrived in Finland in 2015 and been granted asylum quite quickly, within only 10 months. Like many of the migrants who had successfully reunited with their families, Reza came from a wealthy family and had economic resources; he had been able to sell his house in Afghanistan to cover the family reunification costs. However, his family had faced several hardships during the process. One difficulty was the dangerous journey to the government office to deal with the paperwork, such as legalising the marriage documents and getting passports to travel to the interview. Reza explains that during his family's travels, 'on some occasions, there was 10-minute difference between them and a suicide attack.' However, Reza's former social position and his networks in Afghanistan enabled him to find a man he could hire to travel with the family back and forth to India:

We didn't have a problem with the interview in India, but the problem was the number of times the family had to go back and forth. Getting Indian visas was very hard, and the process financially heavy. For example, the Indian embassy in Afghanistan has given the visa process to a company with strict regulations. Every person needs to have bank statement showing that they have 1000 euros in their account, and the money has to have been in the account six months before. Most people in Afghanistan do not have 1000 euros in their bank account.

Due to such impossible requirements, even Reza - a man with many resources - had difficulties in acquiring a visa for India. In addition, he had to pay extra fees to corrupt government officials to obtain passports and other documents for the application. It can be argued that the impossible administrative barriers created by the Finnish immigration policy (such as not being able to submit one's application at the nearest embassy), feed exploitation and even the criminal behaviour of corrupted officials. Reza's case was not exceptional. Many interviewees described how they had significant difficulties in acquiring visas for travel, although they all had valid reasons for travelling to the family reunification interviews. Travel was also extremely dangerous for some interviewees. A 37-year-old Afghan man, Asghar, described how the security situation in Afghanistan made it very difficult to go through with the process:

I had to re-book the appointment four times in the embassy [in New Delhi] and they were wondering why I did this. One time the Taliban bombed the airport and the ticket that I bought for 1300 dollars went to waste. The flight was cancelled....When there was a suicide attack, the offices were closed for two months and no-one was working there or going there. They were saying: 'Come next week, next month.' There was a lot of trouble.

Asghar's wife managed to pay for travel to the interviews, and to hire a translator to accompany her, with the money she got from selling her jewellery. However, these economic resources did not shield the family from the effects of the insecure situation in Afghanistan. The procedure of acquiring documents and travelling to the 
several interviews in India had been an enormous struggle for Asghar's family.

It was common that the families who had been reunited had exhausted all their economic resources in the process. One Iraqi man, Ali, came from a wealthy family and had been well-off in Iraq working as a high government official. Being college-educated, he had cultural resources in the form of language skills and knowledge of government procedures. He had sold his house and all of his possessions to enable the lengthy family reunification process. Nonetheless, he ended up 8000 euros in debt and without any of his former possessions left. He had exhausted all of his resources, and the family was now living on small state subsidies while he struggled to save money to repay the loans.

Ali's, Asghar's, and Reza's cases are similar to those of the other forced migrants who have been able to reunite with their families. Firstly, they had all been exempt from the income requirement, which seemed to be decisive as to whether the process was possible at all. In addition to grounds for residency, all but one family had economic resources as well as social resources in the form of networks in the country of origin. The one family that had very little resources had been reunited before the 2011 legislative change which decreed that families had to start their applications abroad and that Afghans had to apply from India. The participants also often shared the experience that their possessions and wealth had been exhausted during the process, so when their families finally reached Finland, their economic resources were gone and could not be used to help build a new life in Finland.

\subsection{The Wait}

Of those involved in the study, 17 participants were still awaiting final decisions on appeals against the rejection of their applications. A number of scholars have found that long waiting periods in connection with asylum applications and family reunification are detrimental to refugees' well-being (e.g., Leinonen \& Pellander, in press; Vitus, 2010), and the participants in this study were no exception. They all spoke about serious mental health concerns such as anxiety, depression, and insomnia, and in two cases the participants had even attempted suicide after learning of the negative decisions on their applications.

Ahmed, a 35-year-old college-educated man from Iraq, had received his residence permit on the basis of subsidiary protection. He had been well-off in Iraq, and he had some savings as well as property. However, his economic resources did not help him with his family reunification application in Finland, as the Immigration Office required him to show proof of a high salary. His subsidiary protection status meant that he had to show he was earning 2900 euros after tax for his application to reunite with his wife and three small children to be successful.
Ahmed's initial application had been declined as at the time he had only had one job, which provided him with a little over 1000 euros per month after tax. He had appealed this and had managed to acquire a second job giving him a total income of a little over 2000 euros per month after tax, thus closer to the required income. However, his two jobs made it difficult for Ahmed to find time to rest. He started his job as a postman at midnight and finished at around $5 \mathrm{am}$. His second job started at 8 am and lasted until $4.30 \mathrm{pm}$. He only had a couple hours in between to eat and sleep. He was exhausted during our interview, but he wanted to share his story. In the following extract, I have just asked Ahmed about the consequences of the failed family reunification process:

They prevented me from living my normal life....I don't know what I am going to do more than that. There are no more things to be done than having two jobs. Is there something more I could do? You are a Finn, and this is your mother tongue, and as you can see it is clear that I speak neither Finnish nor English, only a little bit. How could I earn that amount of money to bring my family?

Ahmed had economic and social resources, which had helped him to arrange for his family to travel to the interview in Ankara with ease. He had also rented a house for his family so that they could safely await the decision in Turkey. He had friends in Turkey who were taking care of his family while they were waiting there. However, at the time of our interview, the family's visas were due to expire, since the application process had been much longer than he had anticipated. He told us that he had exhausted his economic resources in arranging for longer visas, and his social resources in trying to find places for his family to stay. He now felt hopeless in terms of keeping his family safe. So, for Ahmed, neither having access to economic nor social resources had been enough to bring his family to safety. Moreover, although Ahmed himself possessed cultural resources in the form of education, he explained that his children had not been able to go to school for a full year. This was a source of great despair to him. 'The hopes they had, the Finnish language that they started to learn since they were in Iraq, everything has gone, their future has been ruined,' Ahmed said.

Like Ahmed, Mohammed was another 35-year-old Iraqi father of three. He was awaiting a decision on family reunification while his wife and three children were stuck in a refugee camp. Mohammed also had received residency on the basis of subsidiary protection and was required to have a high income for family reunification. Recently, his father had threatened to kill Mohammed's wife and children because Mohammed had converted to Christianity. The family had had to flee Iraq, where they had initially been living while awaiting Mohammed's asylum decision and the possibility to join him in Finland. Unlike Ahmed, Mohammed had no resources to help his 
wife and three children in their flight. He described the family as sick and living in extremely poor conditions, which was a source of great distress to him. He felt that he had failed as a father and a man. He was unable to read and write in his native tongue and had not been able to get a job, so he had very few resources to influence the situation. He said that he had already tried to commit suicide and saw no purpose in living:

It is not just difficult. Death is better. It is better because they forget about you when you die. What's the meaning of your life when your children are away and your wife is away, and you are disconnected? What is the meaning of life in that case, or what kind of future?

All participants, regardless of the resources available to them, were in a state of high anxiety. This was the case for those from families with status and wealth, as much as for those who were illiterate and had no money. The decisive factor in a prolonged wait seemed to be one's grounds for residency, rather than access to resources. The amount of resources became an important factor only in cases where the forced migrants had received formal refugee status, which enabled family reunification without the high-income requirement. Although reunification was difficult or near impossible even for those with refugee status, other statuses made it entirely impossible for the participants in this study. However, as the examples of Ahmed and Mohammed show, economic, cultural, and social resources played a part in how participants were able to at least make some attempt to fulfil the income requirements and arrange for their families' safety in transit countries. Nonetheless, regardless of resources, the border regime separated families on the basis of mere administrative categories.

\subsection{Risk of Permanent Separation}

Eleven of the participants were facing the risk of permanent family separation. Most of these participants (8) were unaccompanied minors whose single mothers and younger siblings were living in Iran as undocumented migrants. These families had no possibilities to obtain the documentation needed for passports, or the economic resources for travel. Many of the unaccompanied minors' families had not even submitted an application because their chances of getting to the interview were so slim.

I interviewed only a few adults whose applications had been already denied at all the different court levels. Two families were UNHCR-resettled refugees who had already lived in Finland for several years. These were single mothers who had applied for the father to join the family. In both cases, the father had later followed the family to Finland as an asylum seeker but had not received asylum or residency based on family reunification. Both of the fathers had escaped deportation and were in hiding at the time of our interviews. One Somali family, whose father and oldest daughter were living in Finland, had tried to reunite with the mother and five younger children who were living in a refugee camp in a transit country, but their application had failed due to some perceived contradictions in the family members' stories. One man had tried to reunite with his mother, who was alone and in ill health living as a refugee in Turkey, but he had failed to prove her total dependency on him. All of these families shared a background of extreme poverty.

Although the suffering caused by permanent separation was devastating and had caused many of the participants severe hardship, the young unaccompanied minors in particular had been able to regain some agency after first grieving over their circumstances. Many wanted to devote their lives to improving their families' situations. One unaccompanied minor, Hamid, now 20 years old, was making plans to secure his family's residency in Turkey after his application had failed at the Finnish Immigration Service and Administrative Court. He had now abandoned his dreams of high education and was working in construction so as to be able to save for a house for his family:

I have searched a lot. In Turkey, if someone can buy a house in Turkey, they give a residence permit to all of your family members. I am trying to make my job permanent, so as to be able to get a loan from a bank and buy a house there. And when they get to stay there, I also most probably will have been able to get my citizenship. I would be able to go there or come back whenever I want, without any problem.

The unaccompanied minors, who had come to Finland often without ever going to school, and thus were unable to read or write, had been able to acquire cultural resources through schooling in Finland. This had had an impact on what they now desired for their families. Hassan, a 19-year-old Afghan boy, felt strongly that he wanted to lift his siblings out of poverty and illiteracy:

I am worried for my sister and brother now, because everyone in the new generation is literate. I want them to have a future. My brother is a tailor [in a sweatshop]. I do not want him to be a tailor in the future. Even if he becomes a tailor, I want him to at least to be literate. I want him to have an understanding, because everything is more difficult for illiterates. It is difficult to live, to continue their lives. For example, if they have children, they don't know how to raise them.

Since Hassan's family did not have the tazkiras that are needed for passports, and had no way of travelling to India, they had not even tried to submit an application to reunite the family. Instead, he wanted to start providing for his family so that they could rise from poverty and his siblings could avoid sharing his own fate of illiteracy. Hassan had very little previously acquired resources, but 
he had been able to gain cultural resources through his schooling in Finland.

The families in the study who faced permanent separation all shared a background of poverty and had very little in the way of previously acquired resources. While the adults facing permanent separation were often desperate, the unaccompanied minors did have hopes and dreams. Most of the participants who had arrived as unaccompanied minors had acquired significant new cultural and social resources in Finland, and all had hopes of bettering their families' lives with their new resources. However, both the adults facing permanent separation and the unaccompanied minors alike were often the main providers for their transnational families. This created significant difficulties in building a new life in Finland.

\section{Conclusion}

This article investigated forced migrants' resources in connection with possibilities to reunite with their families. Utilizing Bourdieu's theory of capitals in analysing different types of resources, I have investigated the process of family reunification as the 'field' in which different resources may or may not be of value. I use the concept of resources instead of capital, since the forced migrants in this study were able to use various economic, cultural, and social assets in their family reunification processes, but these resources were not necessarily transferrable into valuable symbolic capital (see also Anthias \& Cederberg, 2009).

The most striking finding in this study is that the migrants, who had been successful in their family reunification, had all received a formal refugee status (asylum). Family reunification was not attainable for those with other statuses. The refugee status exempted the interviewees from the high-income requirement and thus enabled them to have a chance to reunite with their families. It was in these instances that social class become a factor in the process. Those participants who had significant capital were the ones who were successful in the process. Vulnerable migrants without education and economic resources struggled enormously, even with the refugee status.

Since family migration scholarship has been focused on other migration patterns, such as labour migration, the specific features of forced migration and family relationships have not been widely investigated. Forced migrants face great difficulties in finding jobs to fulfil the income requirements. Their transnational social ties are also often weak or completely severed. Countries from which migrants are forced to leave also often suffer from corruption. These issues hinder the fulfilling of requirements, arranging the application process and attaining the needed documents for the family to travel. This makes the effect of the residency status (whether this exempts them from income requirements or not) stand out as a decisive factor in a successful process.
However, social, cultural, and economic resources did influence the way in which participants were able to navigate the complicated process if they had refugee status. This study did not fully discuss how different capitals influenced the ways in which forced migrants were able to build their lives after facing permanent family separation. It is presumed that different capitals influence this process greatly.

The analysis shows that economic resources-in the form of property which one could sell, or savings which could be used to cover the costs of the expensive applications - were the most essential for reuniting with one's family if the 'sponsoring' migrant had refugee status in Finland. Cultural resources were important for trying to make sense of the complicated application process, and for finding work or educational possibilities in the new country. Social resources in the country of origin, or countries along the way, proved to be useful for making complicated arrangements for the transnational family's safety. The different resources were also intertwined: Having cultural resources meant that one consequently had wider networks of influential people in the country of origin. This was also connected with having more economic resources to draw on, in the form of either access to loans or one's own wealth.

The group of interviewees who were facing the risk of permanent family separation had very few existing resources before migration. Most of them were unaccompanied minors. They were often unable to read and write in their native tongue, or had very limited education, and their families lived in poverty. It could be argued that the current legislation and the actual administrative procedure fails to protect the most vulnerable forced migrants' family lives.

The literature on migrant capital suggests, for example, that migration results in new ways of producing cultural capital. Research suggests that migrant capital builds on power relations of both the country of origin or the country of migration (Erel, 2010), and social capital is formed through both host society's and co-ethnic social ties (Katila \& Wahlbeck, 2013). The participants in this study utilized a variety of resources to advance their goal of reuniting with their families. However, the fate of the migrants in this study was wrapped around their immigration status in a way which often sealed their destinies. The 'waiting' category, which I investigated in this article, included wealthy migrants with economic, social, and cultural capital as well as migrants with almost no capital at all. So, while economic capital and other capitals were certainly useful in many ways, they are not the most significant factor in these cases.

This article aimed to provide an overall analysis of the situation of forced migrants' struggles for family reunification in Finland. Further studies are needed to shed light on how migrants cope with prolonged family separation and how (if at all) the acquisition and usage of migrant capital is connected to coping with permanent family separation. 


\section{Acknowledgments}

Special thanks to research assistants Elina Jokinen, Nita Toom, Zeinab Karimi, Ahmed Zaidan and Edris Bayan Shenwarai. This research was conducted in the project Family Separation, Migration Status and Everyday Security (led by Marja Tiilikainen), funded by the Academy of Finland. Grant number: 308249.

\section{Conflict of Interests}

The author declares no conflict of interests.

\section{References}

Anthias, F. (2007). Ethnic ties: Social capital and the question of mobilisability. The Sociological Review, 55(4), 788-805.

Anthias, F. (2012). Transnational mobilities, migration research and intersectionality. Nordic Journal of Migration Research, 2(2), 102-110.

Anthias, F., \& Cederberg, M. (2009). Using ethnic bonds in self-employment and the issue of social capital. Journal of Ethnic and Migration Studies, 35(6), 901-917.

Bourdieu, P. (1986). The forms of capital. In J. Richardson (Ed.), Handbook of theory and research for the sociology of education (pp. 241-258). New York, NY: Greenwood Press.

Bourdieu, P. (1987). What makes class? Berkeley Journal of Sociology, 32, 1-18.

Cederberg, M. (2015). Embodied cultural capital and the study of ethnic inequalities. In L. Ryan, U. Erel, \& A. D’Angelo (Eds.), Migrant capital. networks, identities and strategies (pp. 33-47). London: Palgrave Macmillan.

Choummanivong, C., Poole, G. E., \& Cooper, A. (2014). Refugee family reunification and mental health in resettlement. Kōtuitui: New Zealand Journal of Social Sciences Online, 9(2), 89-100.

Crawley, H., \& Hagen-Zanker, J. (2019). Deciding where to go: Policies, people and perceptions shaping destination preferences. International Migration, 57(1), 20-35.

de Hart, B. (2007). The right to domicile of women with a migrant partner in European immigration law. In T. Spijkerboer \& S. Van Walsum (Eds.), Women and immigration law: New variations on classical feminist themes (pp. 142-62). Abingdon and New York, NY: Routledge-Cavendish.

della Puppa, F. (2018). Ambivalent mobilities and survival strategies of Moroccan and Bangladeshi families in Italy in times of crisis. Sociology, 52(3), 464-479.

Eggeb $\varnothing$, H. (2013). A real marriage? Applying for marriage migration to Norway. Journal of Ethnic and Migration Studies, 39(5), 773-789.

Erdal, M. B., \& Oeppen, C. (2018). Forced to leave? The discursive and analytical significance of describing migration as forced and voluntary. Journal of Ethnic and Migration Studies, 44(6), 981-998.

Erel, U. (2010). Migrating cultural capital: Bourdieu in migration studies. Sociology, 44(4), 642-660.

Katila, S., \& Wahlbeck, Ö. (2012). The role of (transnational) social capital in the start-up processes of immigrant businesses: The case of Chinese and Turkish restaurant businesses in Finland. International Small Business Journal, 30(3), 294-309.

Kofman, E. (2018). Family migration as a class matter. International Migration, 56(4), 33-46.

Koser, K., \& Pinkerton, C. (2002). The social networks of asylum seekers and the dissemination of information about countries of asylum. London: Migration Research Unit, University College London.

Krause, U. (2017). Researching forced migration: Critical reflections on research ethics during fieldwork. Oxford: Refugee Studies Centre, University of Oxford.

Leinonen, J., \& Pellander, S. (in press). Temporality and everyday (in)security in the lives of separated refugee families. In J. Hiitola, S. Gruber, K. Turtiainen, \& M. Tiilikainen (Eds.), Family life in transition: Borders, transnational mobility and welfare society in the Nordic countries. London: Routledge.

Lyytinen, E., \& Kullenberg, J. (2015). Urban refugee research and social capital: A roundtable report and literature review. London: International Rescue Committee and ALNAP.

Mackenzie, C., McDowell, C., \& Pittaway, E. (2007). Beyond 'do no harm': The challenge of constructing ethical relationships in refugee research. Journal of Refugee Studies, 20(2), 299-319.

Mustasaari, S. (2016). Best interests of the child in family reunification: A citizenship test disguised. In A. Griffiths, S. Mustasaari, \& A. Mäki-Petäjä-Leinonen (Eds.), Subjectivity, citizenship and belonging: Identities and intersections (pp. 123-145). London: Routledge.

Nickerson, A., Bryant, R. A., Steel, Z., Silove, D., \& Brooks, R. (2010). The impact of fear for family on mental health in a resettled Iraqi refugee community. Journal of Psychiatric Research, 44(4), 229-235.

Oxford Refugee Studies Centre. (2007). Ethical guidelines for good research practice. Refugee Survey Quarterly, 26(3), 162-172.

Pellander, S. (2015). "An acceptable marriage": Marriage migration and moral gatekeeping in Finland. Journal of Family Issues, 36(11), 1472-1489.

Putnam, R. D. (2000). Bowling alone. The collapse and revival of American community. New York, NY: Simon \& Schuster.

Richardson, R. (2010). Sending a message? Refugees and Australia's deterrence campaign. Media International Australia, 135(1), 7-18.

Rousseau, C., Mekki-Berrada, A., \& Moreau, S. (2001). Trauma and extended separation from family among Latin American and African refugees in Montreal. Psychiatry, 64(1), 40-68.

Rousseau, C., Rufagari, M. C., Bagilishya, D., \& Measham, 
T. (2004). Remaking family life: Strategies for reestablishing continuity among Congolese refugees during the family reunification process. Social Science \& Medicine, 59(5), 1095-1108.

Ryan, L., Erel, U., \& D’Angelo, A. (2015). Introduction: Understanding 'migrant capital.' In L. Ryan, U. Erel, \& A. D’Angelo (Eds.), Migrant capital: Networks identities and strategies (pp. 3-17). London: Palgrave Macmillan.

Sanghera, G. S., \& Thapar-Björkert, S. (2017). Transnationalism, social capital and gender-young Pakistani Muslim women in Bradford, UK. Migration Letters, 14(1), 88-100.

Skeggs, B. (1997). Formations of class and gender: Becoming respectable. London: Sage.
Skeggs, B. (2004). Exchange, value and affect: Bourdieu and 'the self.' The Sociological Review, 52(2), 75-95.

Thomson, P. (2008). Field. In M. Grennfell (Ed.), Pierre Bourdieu: Key concepts (pp. 67-84). Durham: Acumen Publishing.

Valenta, M., \& Thorshaug, K. (2012). Asylum-seekers' perspectives on work and proof of identity: The Norwegian experience. Refugee Survey Quarterly, 31(2), 76-97.

Vitus, K. (2010). Waiting time: The de-subjectification of children in Danish asylum centres. Childhood, 17(1), 26-42.

Wilmsen, B. (2013). Family separation and the impacts on refugee settlement in Australia. Australian Journal of Social Issues, 48(2), 241-262.

\section{About the Author}

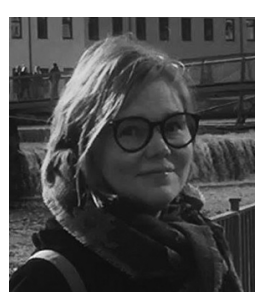

Johanna Hiitola is Senior Researcher at the Migration Institute of Finland and will be starting to work as a Senior Lecturer in Social Work at Tampere University in 2020. She has conducted research on gender and race in child protection, migrant families' welfare services, Afghan mobilities, and family migration. Currently she works in the Academy of Finland funded research project Family Separation, Migration Status and Everyday Security. 